\title{
Cymothales annisancti Navás, 1926 is a valid species (Neuroptera: Myrmeleontidae)
}

\author{
LEVENTE ÁBRAHÁM \\ Rippl-Rónai Museum H-7400 Kaposvár, P.O. Box 70, Hungary, \\ e-mail: labraham@smmi.hu
}

\begin{abstract}
ÁBRAHÁm, L.: Cymothales annisancti Navás, 1926 is a valid species (Neuroptera: Myrmeleontidae).
Abstract: Cymothales annisancti Navás, 1926, formerly kept as a synonym. On the basis of a Cymothales specimen from Republic of Guinea we concluded, it is conspecific with the type of Cymothales annisancti Navás, 1926. The valid taxon is compared to Cymothales liberiensis van der Weele, 1904. With 8 figures.
\end{abstract}

Keywords: antlion, Cymothales, new status, Africa

\section{Introduction}

Myrmeleontidae (antlions) is the richest family in species (more than 1500 described species) of the order Neuroptera (STANGE 2004, Oswald 2019). Most of them are associated with arid habitats: deserts, semi-deserts, savannahs but many species also occur in tropical and subtropical forests.

The antlion fauna of Africa is lesser known. MANSELL (2010) mentioned the occurrence of 58 valid genera 447 valid species based on 273 publications. The number of synonymous taxa is also high (102 generic synonyms and 230 species synonyms). It is likely that descriptions of new species and new synonym taxa will be found in significant numbers in the future.

Only a small part of the African antlion fauna has been revised (eg. MANSELL 1985, 1987, 1990, 1992, 1996, 2018a,b, Michel \& MANSELL 2010).

One of the most imposing genera of medium to large sized species is Cymothales Gerstaecker, 1894, whose distribution extends from the savannahs to the tropical forests of Africa (MANSELL 1987). Its species have significantly different lifestyles than those found in large numbers in dry habitats, as its larva develops in caves of trees (MANSELL 1987, Stange 2004). During the revision (Mansell 1987) of the genus Cymothales, 17 species from Africa were listed. Later, HöLzEL (2001) described a new species from the Southwestern Arabian Peninsula (Yemen) where the vegetation is drought deciduous thorn woodlands and shrublands. The fauna of this area has a strong African influence and it is a transitional area between the Tropical and the Palearctic zone.

Recently, I received a few antlion specimens from Guinea, in which I found a Cymothales specimen with strange colour pattern. After a thorough examination, I found my specimen from Guinea is morphologically conspecific with Cymothales annisancti Navás, 1926, which was considered as synonym name (MANSELL 1987). 


\section{Material and methods}

Cymothales annisancti Navás, 1926

The type is preserved in Musée Royal de 1'Afrique Centrale, Tervuren, Belgium (MRAC) (Fig. 1).

$1 \widehat{0}$ "/ TYPE [red label with double black margins] // Typus [red label with Navás's handwriting] / // Musée du Congo / Barumbu / 11-XII-1920, / L. Ghesquière [blue label in printed letters] // Cymothales / rex Nav. [with Navás's handwriting] / P. Navás S. J. det. [printed] [blue label] // R. DÉT / O / 1203 [white label] // MRAC - Tervuren / database No / MRAC00008 [white label] // CYMOTHALES / LIBERIENSIS / V.D. WHEELE / Det. M. W. Mansell, 1986 [white label with Mansell's handwriting] /"

In Navás (1926a): "Congo belgicus Barumbu 11.XII.1920, L. Ghesquière" Mus. Congo belg."

The type specimen is labelled as "Cymothales rex" by Navás but in Navás (1926a), the name associated with the type of Cymothales annisancti in his paper. The name is attributed by MANSELl (1987) to Navás (1926a) (Oswald 2019).

The type condition is poor, tip of abdomen, several legs and antennae lost, left forewing glued.

The second specimen is preserved in the entomological collection of Rippl-Rónai Museum, Kaposvár (SCMK):

"/ 1 え // NeuMyr931 // WEST AFRICA / Republic of GUINEA / N'Zerekoré Region Mt. Nimba / Ziela SSMN / 535m N7.71559 W8.35710 / 2017.03.12-04.09. / Leg: Gergely Petrányi [white label] // Cymothales annisancti / Navás, 1926 / Det. Ábrahám L. [white label] /" (Fig. 3).

Cymothales liberiensis van der Weele, 1904 (Fig. 2)

New records in the entomological collection of Rippl-Rónai Museum, Kaposvár (SCMK) (Fig. 4).

"/ 19 // NeuMyr928 // Ghana /Eastern Region / Bunso Arboretum / 12-20.X.2009/

Leg: Sáfián Sz., Walker A., Davey S., Onstein R. /"

"/ q // NeuMyr929 // Ghana WLI Volta Region / Agumatsa Hohoe District / N:0706,909' E:00³5,346' / 2005.04.13-15. / Leg: Sáfián Sz., Csontos G., Kormos B. /"

"/ $1 \delta^{\jmath} / /$ NeuMyr930 / Ghana Central Region / Abrafo Kakum Forest / 5²1'26.28"N 1²2'16,61"W / 2009.03.08-11. / Leg: Sáfián Sz. /"

"/ 1 + // NeuMyr931 // Cameroon Southwest Region / Mt. Cameroon Fako District / Bamboo Camp / 14-23.II.2016 / Leg: Sáfián Sz., Tropek R., Maicher V. /"

"/ 19 // NeuMyr931 // WEST AFRICA / Republic of GUINEA / N'Zerekoré Region Mt. Nimba / Ziela SSMN / 535m N7.71559 ${ }^{\circ}$ W8.35710 / 2017.03.12-04.09. / Leg: Gergely Petrányi [white label] // Cymothales liberiensis / van der Weele, 1904/ Det. Ábrahám L. [white label] /"

in USMB - Upper Silesian Museum Bytom Poland

"1우 Burkina Faso, Diabo, 24 VII 1997, leg. D. Skibiński (USMB 5858/1048)"

"1우 Cameroon, Ebogo, $15 \mathrm{~km} \mathrm{~S}$ of Mbalmayo, $90 \mathrm{~km} \mathrm{~S}$ of Yaunde, 4-16 IV 2013, at light, leg. G. Kowalska".

The habitus photos were taken by Canon EOS 400 digital camera equipped with flash light system (Sigma EM140 DM). The layers of photos were processed with Adobe Photoshop software. 


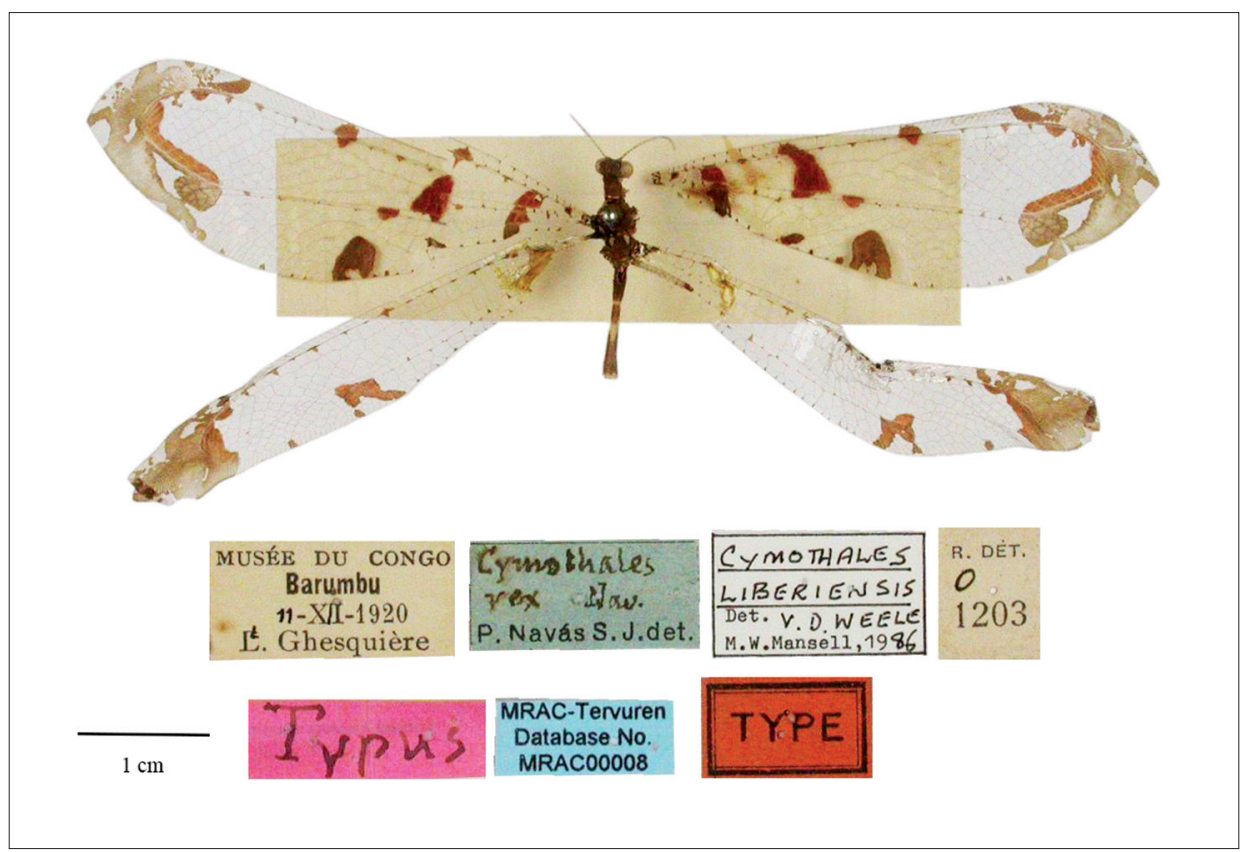

Fig.1: Type of Cymothales annisancti Navás, 1926 preserved in MRAC, Tervuren

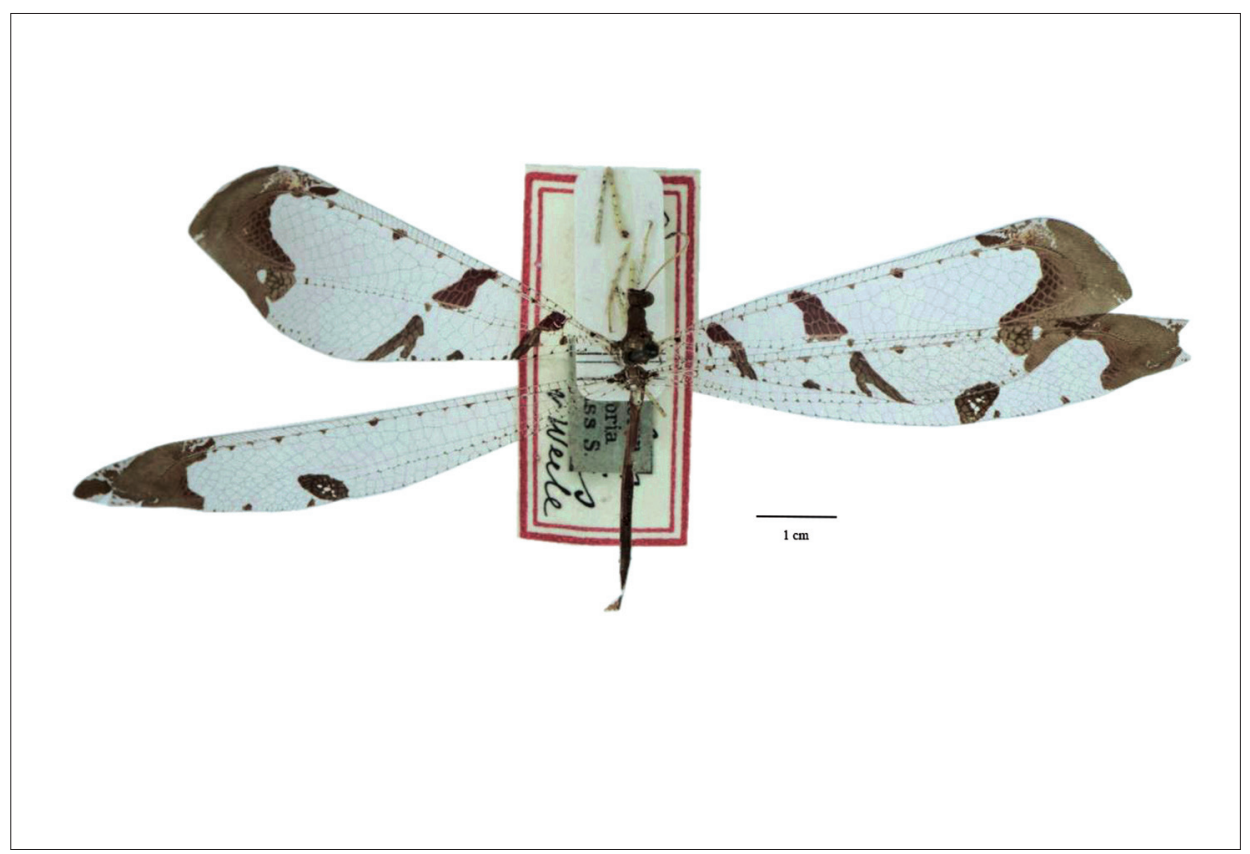

Fig. 2: Type of Cymothales liberiensis van der Weele, 1904 preserved in ZMHB, Berlin 


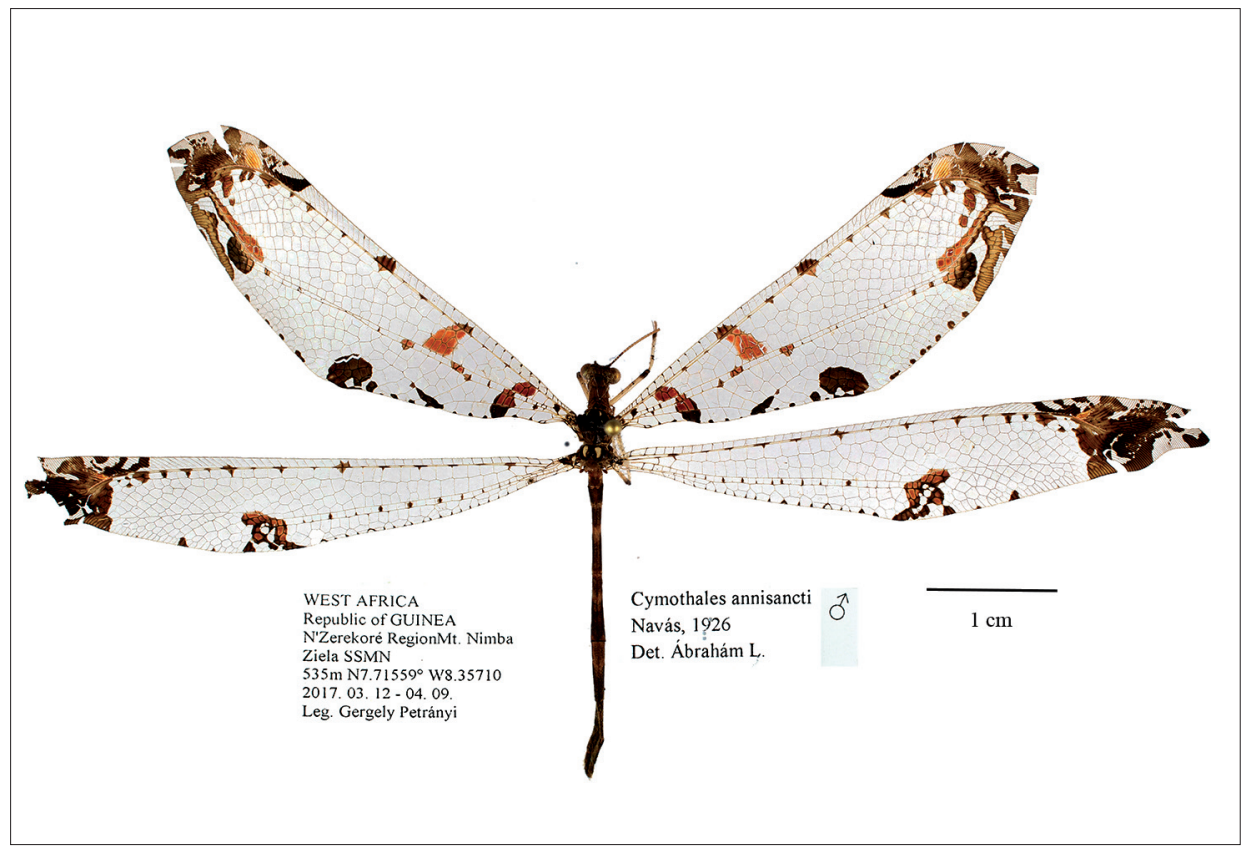

Fig. 3: Habitus of the second specimen of Cymothales annisancti

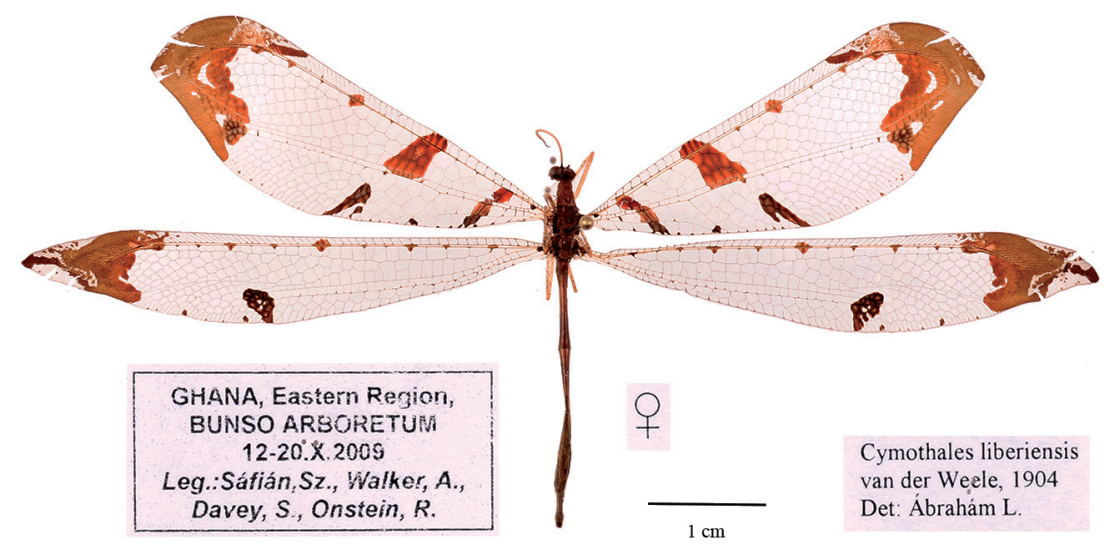

Fig. 4: Habitus of Cymothales liberiensis 


\section{Results and discussion}

From Guinea, in the specimens of the identified material were greater morphological differences between the two Cymothales specimens. Based on MANSELL's (1987) paper, one of them proved to be Cymothales liberiensis van der Weele, 1904 but the other one was different. Later I also checked the synonymous type specimens and found Cymothales annisancti Navás, 1926 in the collection of Musée Royal de 1'Afrique Centrale, Tervuren, Belgium (MRAC) to be the same with my specimen. The type specimen is in poor condition, antennae most of the legs and the end of the abdomen are missing but it could still be found that the specimen collected in Guinea was conspecific with the type specimen of Cymothales annisancti Navás, 1926 and taxonomic status is valid.

Therefore, I give a more detailed characterization and illustrations of the second known specimen of this species, in order to make it easier to distinguish between the two species in the future.

Characters for Cymothales annisancti Navás, 1926

Head. Vertex square shaped in frontal view, dull brown and hairless; frons, clypeus and labrum shiny brown entirely, clypeus margins with sparse shiny brown hairs, labrum with sparse shiny ocher-brown hairs directed ventrally. Gena brown with small yellow spot above arising mandibula, hairless (Fig. 5). Antenna clavate. Scape, pedicel brown, dispal part of pedicel with narrow yellow ring. Flagellomeres (1-5) brown dorsally, others yellow dorsally and ventrally. Mandible shiny brow with black inner margin. Maxillar and labial palps brownish yellow. Eyes large and shiny bronze brown. Goitre shiny brown (only on male) present, sclerotized sac-like structure on the postmentum. (Fig. 6).

Thorax: Pronotum at least twice longer than wide, light brown, with two small yellow stripes dorso-laterally and with narrow yellow lateral margin on prescutum. Pronotum with sparse outstanding pale hairs laterally. Mesonotum and metanotum dark brown with two distinct yellow stripes on mesoprescutum and metascutum. Pubescence on mesonotum and metanotum sparse very short pale. Pleurites dark brown with distinct yellow margins along suturae and with sparse short pale hairs.

Legs: (Fig. 6) coxae brown; trochanters, femora, tibiae slender, yellow with a few dark brown spots and sparse short outstanding black bristles in two rows ventrally. Narrow brown ring on distal parts of femora and tibiae. Femora as long as tibiae. Tarsal segments yellow with short pale bristles. Basitarsi as long as tarsal segment 5 on fore and middle legs. Tarsal segment 1 sligthly longer than tarsal segment 5 on hind leg. Tibial spurs as long as tarsal segment 1-2 combined.

Wings. Narrow hindwing is longer than board forewing, tip of wings subacute but not falcate, pattern on wing bicoloured dark brown and dark burgundy (Fig. 7). In forewing complete basal band oblique bicoloured, sectoral band divided out, long oval shaped in originating of radial sector, slightly oval shaped on hind margin. Pattern in apical area strongly fragmented. Pterostigma yellow with 4-5 forked pinkish veins. Presectoral area with 2 crossveins and 6 irregular double cells. Rs with 8-12 branches.

Tip of hindwing subacute and falcate, pattern in apical area and on hind margin also fragmented. Pterostigma small brown with 3 pinkish veins. Presectoral area with 1 crossvein. Rs with 12-14 branches.

Abdomen. Shorter than wings. Tergites brown with indistinct oval yellow spot on tergite 2-5 dorso-medially. Sternites yellowish-brown. Pubescence short, pale. 


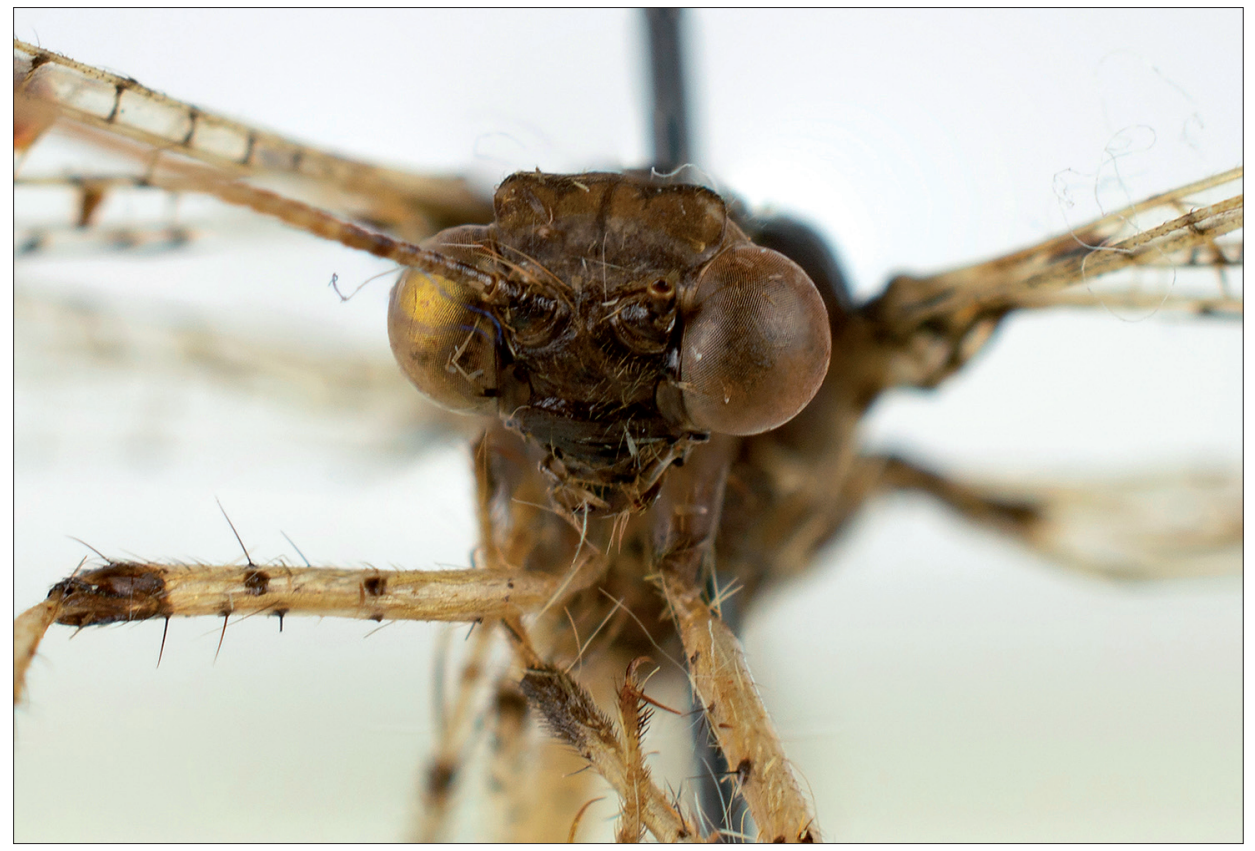

Fig. 5: Head of the second specimen of Cymothales annisancti in frontal view

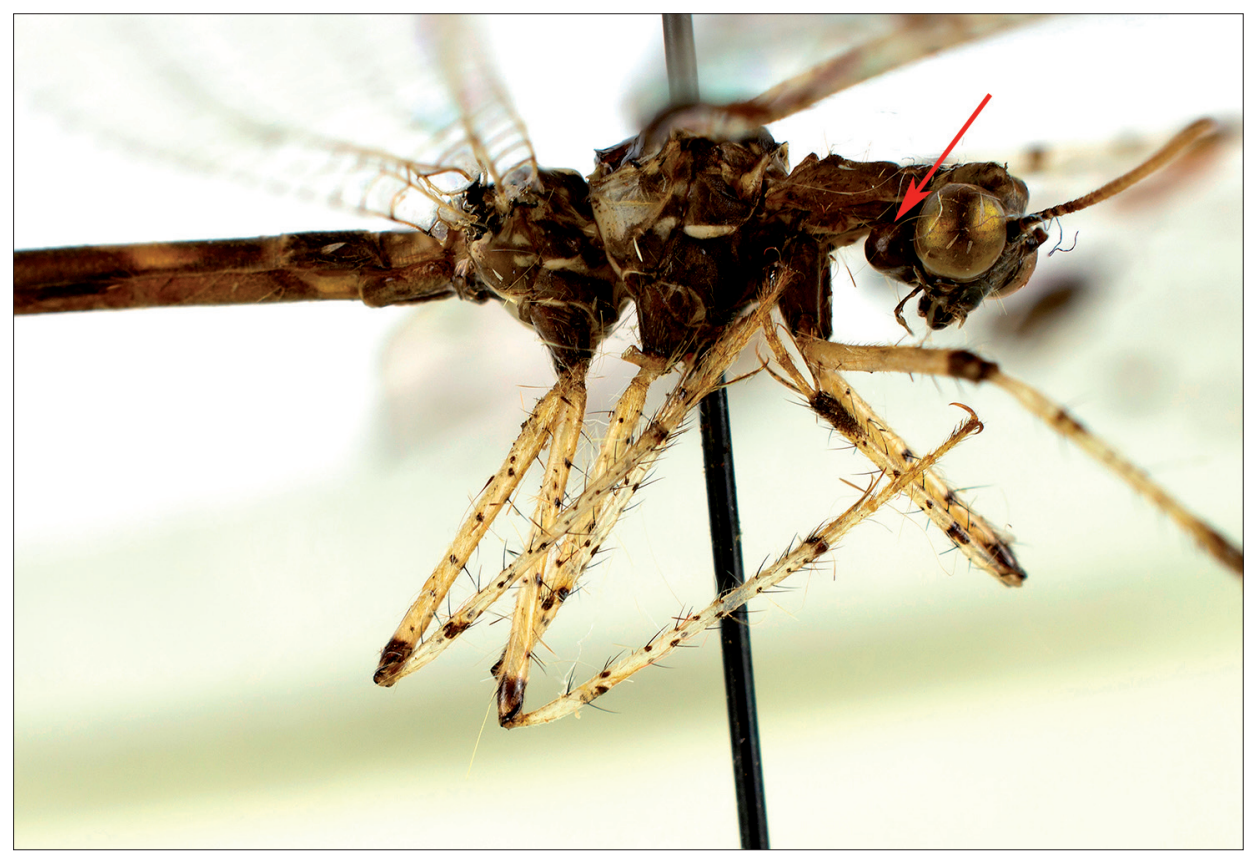

Fig. 6: Legs and goitre of Cymothales annisancti in lateral view, red arrow shows the goitre 


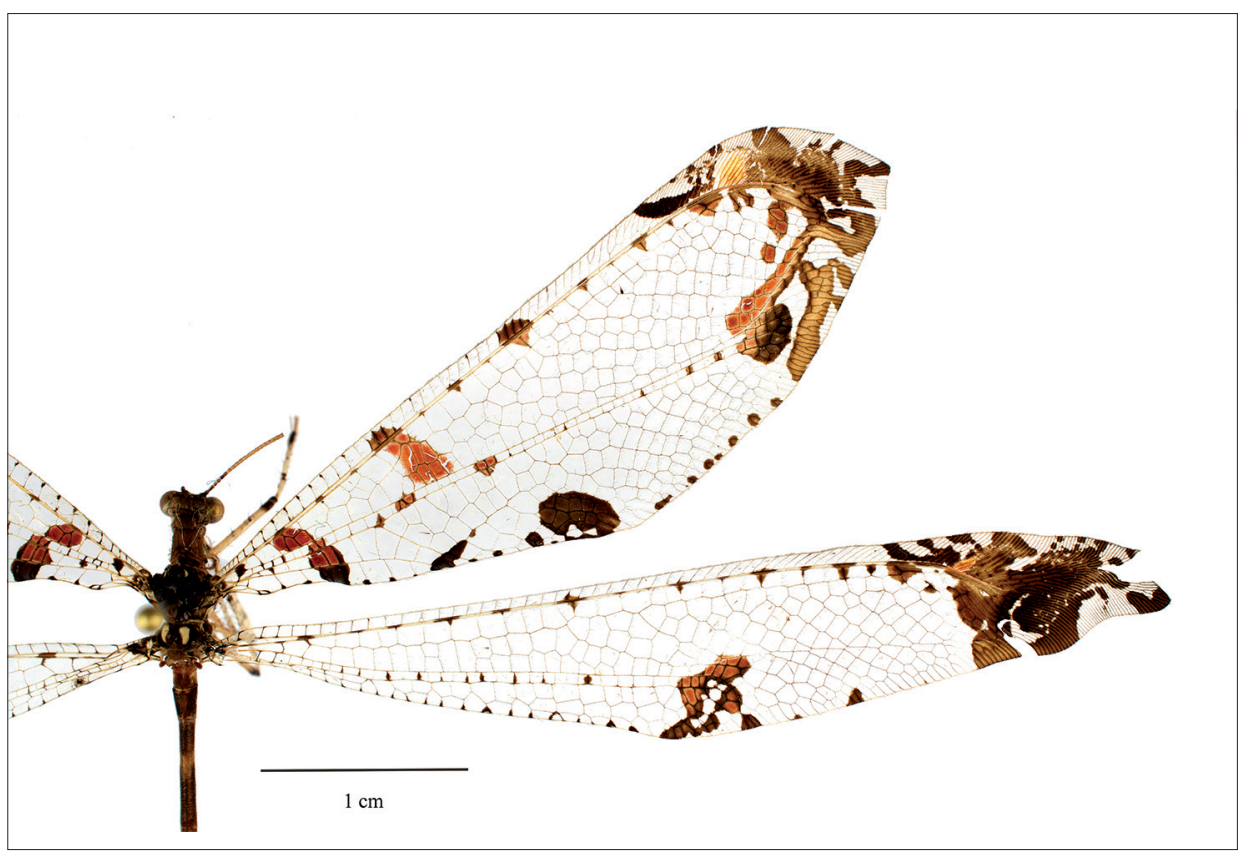

Fig. 7: Wings of the second specimen of Cymothales annisancti

Table 1: Differncial characters between Cymothales annisancti and Cymothales liberiensis

\begin{tabular}{|l|l|l|}
\hline Differencial characters & C. annisancti & C. liberiensis \\
\hline Submentum & brown & pale \\
\hline Pronotum & brown with 2 yellow spots & unicolour brown \\
\hline Goitre (male) & present & absent \\
\hline $\begin{array}{l}\text { Sectoral band pattern on } \\
\text { hind margin }\end{array}$ & oval shaped mark & rectangle shaped mark \\
\hline $\begin{array}{l}\text { Pattern in apical area in } \\
\text { forewing }\end{array}$ & $\begin{array}{l}\text { strongly fragmented } \\
\text { bicolour }\end{array}$ & $\begin{array}{l}\text { less fragmented uniformly } \\
\text { brown }\end{array}$ \\
\hline $\begin{array}{l}\text { leg pattern on distal parts } \\
\text { of femora and tibiae }\end{array}$ & narrow brown ring & without any patterns, pale \\
\hline $\begin{array}{l}\text { Tergites } \\
\text { brown with larger indis- } \\
\text { tinct yellow spots }\end{array}$ & unicoloured brown \\
\hline Sternite 9 in ventral view & distal edge incised & distal edge arched \\
\hline
\end{tabular}




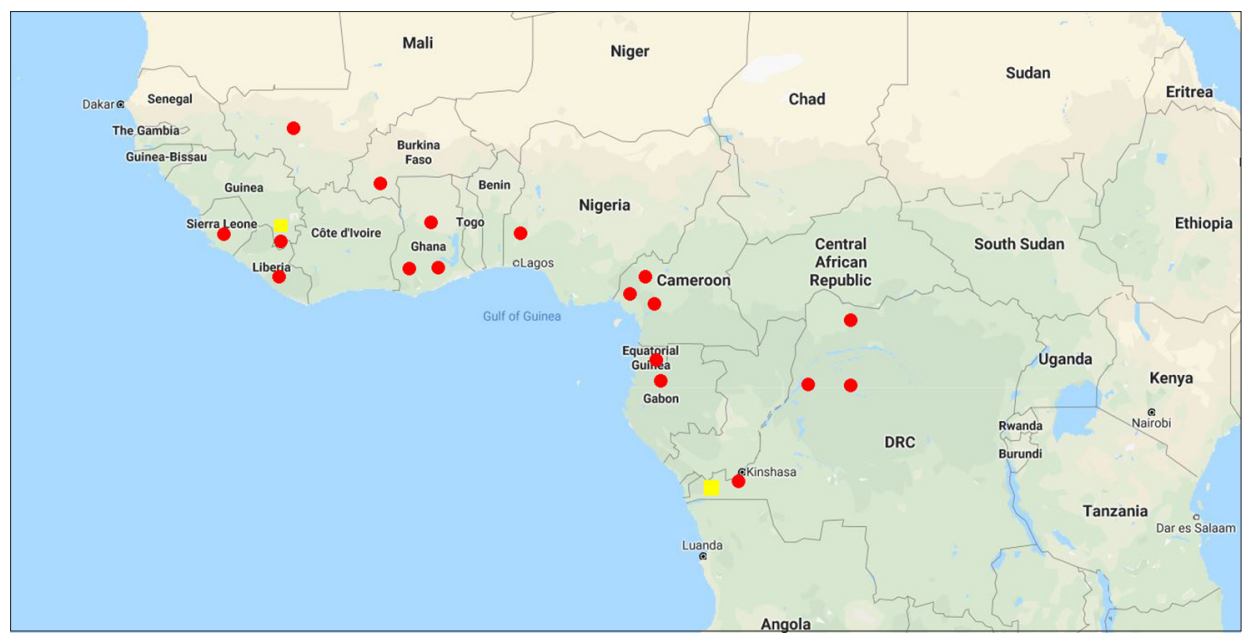

Fig. 8: Distribution of Cymothales liberiensis (red cirle) and C. annisancti (yellow quadrat)

Distribution: Both species spread from tropical West Africa to tropical central Africa. (Fig. 9)

Cymothales annisancti Navás, 1926

Zaire (Navís 1926a, 1926b), Guinea (a new record for the fauna in coll. SCMK).

Cymothales liberiensis van der Weele, 1904

Distribution in Africa: Burkina Faso (Prost 2015), Cameroon (van Der WeELE 1905, Banks 1911, Mansell 1987, Prost 2015), Ghana (a new record for the fauna in coll. SCMK), Guinea (Klapálek 1906, Prost 2015), Gabon (Auber 1956, Prost 2015), Ivory Coast (Auber 1956, Prost 2015), Liberia (vAN Der Weele 1904, type), Mali, Nigeria (MAnsell 1987, Prost 2015), Sierra Leone (BAnks 1911), Zaire (NAvás 1911, 1919 [1921], 1925, 1929, 1936, Mansell 1987, Prost 2015).

Species of the genus Cymothales occur only in the Afrotropical zone. Cymothales vanharteni Hölzel, 2001, found in the southern Arabian Peninsula, proves that this area is also heavily influenced by African fauna. According to MANSELL's (1987) revision, most species in the genus can be divided into two groups: the illustris-group and the mirabilis-group, Cymothales liberiensis and Cymothales annisancti belong to the mirabilis-group.

Mansell (1987) did not mention of the goitre. The functional role and potential taxonomic significance of goitre is unknown (Stange, 2004, KrivothatsKy 2011), it is present in several tribes eg. Dendroleontini, Myrmecaelurini, Brachynemurini.

\section{Acknowledgement}

The author thanks Gergely Petrányi (Hungary) for collecting the antlion specimen during his field research and handing them over to the collection of the Rippl-Rónai Museum, Kaposvár. 


\section{References}

Auber, J. 1956: Névroptères Planipennes récoltés en Côte-d'Ivoire par la mission Paulian-Delamare. - Bulletin de l'Institut Française d'Afrique Noire (Series A, Sciences Naturelles) 18: 495-499.

Banks, N. 1911: Notes on African Myrmeleonidae. - Annals of the Entomological Society of America 4: $1-[31]$.

HöLzel, H. 2001: Neue Taxa der Myrmeleontidae aus Arabien (Insecta: Neuroptera). - Linzer Biologische Beitrage 33: 977-988.

KLAPÁLEK, F. 1906: Dos Neurópteros de la Guinea Española. - Memorias de la [Real] Sociedad Española de Historia Natural 1: 323-326.

KrivoкнатsкY, V. A. 2011: Муравьиные львы (Neuroptera: Myrmeleontidae) России [=Antlions (Neuroptera: Myrmeleontidae) of Russia]. - Товарищество Научных Изданий KMK [=KMK Scientific Press], СанктПетербург [=St. Petersburg]. 334 pp.

Mansell, M. W. 1985: The ant-lions of southern Africa (Neuroptera: Myrmeleontidae). Introduction and genus Bankisus Navás. - Journal of the Entomological Society of Southern Africa 48: 189-212.

Mansell, M. W. 1987: The ant-lions of southern Africa (Neuroptera: Myrmeleontidae): genus Cymothales Gerstaecker, including extralimital species. - Systematic Entomology 12: 181-219. https://doi.org/10.1111/ j.1365-3113.1987.tb00195.x

Mansell, M. W. 1990: The Myrmeleontidae of southern Africa: tribe Palparini. Introduction and description of Pamares gen. nov., with four new species (Insecta: Neuroptera). - Journal of the Entomological Society of Southern Africa 53: 165-189.

Mansell, M. W. 1992: The ant-lions of southern Africa: genus Pamexis Hagen (Neuroptera: Myrmeleontidae: Palparinae: Palparini). - Systematic Entomology 17: 65-78. https://doi.org/10.1111/j.1365-3113.1992. tb00322.x

Mansell, M. W. 1996: The antlions of southern Africa (Neuroptera: Myrmeleontidae): genus Palparellus Navás, including extralimital species. - African Entomology 4: 239-267. https://doi.org/10.11646/ zootaxa.4382.3.3

Mansell, M. W. 2018a: Antlions of southern Africa: genus Crambomorphus McLachlan, 1867, including extra-limital species (Neuroptera: Myrmeleontidae: Palparinae: Palparini). - Zootaxa 4382: 465-500. https://doi.org/10.11646/zootaxa.4382.3.3

Mansell, M. W. 2018b: Antlions of southern Africa: Syngenes Kolbe, 1897, with descriptions of two new species and comments on extra-limital taxa (Neuroptera: Myrmeleontidae: Acanthaclisini). - Zootaxa 4497: 346-380. https://doi.org/10.11646/zootaxa.4497.3.2

Michel, B.; Mansell, M. W. 2010: Revision of the genus Ganguilus Navás (Neuroptera, Myrmeleontidae) with descriptions of three new species. - Zootaxa 2389: 1-24.

Navís, L. 1911: Notes sur quelques Névroptères d'Afrique. I. - Revue de Zoologie Africaines, Bruxelles 1: 230-244.

NAvís, L. 1919 [1921]: Comunicaciones entomológicas. 3. - Insectos exóticos. Revista de la [Real] Academia de Ciencias Exactas Fisico-Quimicas y Naturales de Zaragoza (1)4: 287-306.

Navás, L. 1925: Insectes du Congo Belge. - Série I. Revue de Zoologie Africaines, Bruxelles 13: 123-132.

Navís, L. 1926a. Insecta nova. Series XI. Memorie dell'Accademia Pontifica dei Nuovi Lincei, Rome (2)9: 101-110.

Navás, L. 1926b: Insectes du Congo Belge. Série II. - Revue de Zoologie Africaines, Bruxelles 14: 85-90.

Navás, L. 1929: Insectes du Congo Belge (Série III). - Revue de Zoologie et de Botanique Africaines 18: 92-112.

Navís, L. 1936: Insectes du Congo Belge. - Série IX. Revue de Zoologie et de Botanique Africaines 28: 333368.

Prost, A. 2015: Notes sur la dispersion géographique en Afrique de quelques Cymothales (Neuroptera Myrmeleontidae Dendroleontini). - Entomologiste 71: 351-352.

StANGE, L. A. 2004: A systematic catalog, bibliography and classification of the world antlions (Insecta: Neuroptera: Myrmeleontidae). - Memoirs of the American Entomological Institute 74: [iv]+565.

van der Weele, H. W. 1904: New and little-known Neuroptera. - Notes from the Leyden Museum 24: 203215.

van DeR Weele, H. W. 1905-1907: Über die von Prof. Dr. Y. Sjöstedt auf seiner Reise in Kamerun gesammelten Planipennia. - Arkiv för Zoologi 3(2): 1-14. 
